\title{
Italian credit cooperative banks: the fundamental role in supporting the growth of SMEs and family businesses
}

\section{Chiara Crovini*, Giovanni Ossola and Guido Giovando}

Department of Management,

School of Management and Economics,

University of Turin,

C.so Unione Sovietica 218/bis, 10134, Turin, Italy

Email: chiara.crovini@unito.it

Email: giovanni.ossola@unito.it

Email: guido.giovando@unito.it

*Corresponding author

\begin{abstract}
Our research concentrates on the role of Italian credit cooperative banks, supporting the entrepreneurship and the development of SMEs and family businesses. We took into consideration the data of loans, allocated by those banks in 2014. We tried to find the relationship between the banking system and the world of SMEs and family businesses. This research represents the first step of a far deeper analysis. In this stage, we aimed at providing the groundwork for further empirical and qualitative analyses. Therefore, we try to improve the existing literature by using a conceptual approach. Despite the limitations of this research, researchers in the field of SMEs and credit cooperative banks can consider the opportunities for further developments of our analysis. Our findings give evidence that SMEs and family businesses need the support of the credit cooperative banks, in order to further exploit the opportunity to expand their businesses.
\end{abstract}

Keywords: credit cooperative banks; loans to residents; small and medium-sized enterprises; SMEs; family businesses; growth; innovation.

Reference to this paper should be made as follows: Crovini, C., Ossola, G. and Giovando, G. (2018) 'Italian credit cooperative banks: the fundamental role in supporting the growth of SMEs and family businesses', Global Business and Economics Review, Vol. 20, Nos. 5/6, pp.602-611.

Biographical notes: Chiara Crovini is a $\mathrm{PhD}$ candidate in Business and Management at the Department of Management from the University of Turin, Italy. Her research area covers all the topics related to risk management, corporate governance, internal control systems, internal auditing, statutory audit of SMEs, banks and credit institutions. She is member of Accademia Italiana di Economia Aziendale Giovani (AIDEA Giovani), SIDREA (Società Italiana dei Docenti di Ragioneria e Economia Aziendale), International Academy of Business and Economics, BS - Lab. (Business Systems Laboratory) and ERRN (European Risk Research Network). She is a reviewer of Global Business and Economics Review and World Review of Entrepreneurship, Management and Sustainable Development, Inderscience Publishers. She is a Chartered Accountant and Statutory Auditor. 
Giovanni Ossola is a Full Professor in Business Administration at the Department of Management from the University of Turin, Italy. At present, he is teaching business administration in the Bachelor's degree courses and financial accounting and financial statements of banks and credit institutions in the Master's degree courses. He is a Chartered Accountant and Statutory Auditor in many companies. He is a member of Accademia Italiana di Economia Aziendale (AIDEA). He is an author of many national and international publications in the banking and assurance field, financial accounting and airport infrastructure.

Guido Giovando is an Associate Professor in Business Administration at the Department of Management from the University of Turin, Italy. At present, he is teaching business administration and cost accounting in the Bachelor's degree courses and accounting and financial statements of banks and credit institutions in the Master's degree courses. He is a Chartered Accountant and Statutory Auditor in many companies. He is an author of many national and international publications in the banking and assurance field, financial accounting and airport infrastructure. $\mathrm{He}$ is an Associate Fellow of the EuroMed Academy of Business (EMAB).

\section{Introduction}

In the last quarter of 1800 , the credit cooperative developed a new banking system in Italy. Since their origin, the credit cooperative institutions were closely linked to the local communities in which they were located. In fact, thanks to the deep knowledge and reciprocal community members, their family situation, their personal reputations have been identified to creditworthy people.

The first forms of cooperative credit in Italy were the rural and artisans, inspired by Christian values, and they played a key role in stimulating the humble groups of rural people, especially farmers and craftsmen to obtain loans on more favourable conditions than those applied by traditional banks.

Since then, Rural and Artisan banks have maintained a very close relationship with the territory of reference, weaving their own story with that of the communities, as to be 'local banks call'.

In other words, the aim was not to maximise profits, but rather to support the local economy. The role of these banks was, in fact, to carry out lending to people and businesses belonging to their territory in order to promote social and economic development of the community.

In 1993, the Banking Act laid down a radical change even in the name, passing from 'Rural and Artisan banks' to the current 'mutual banks'. This decree did not operate any limitations to BCCs, so they could offer all the products and services of other banks.

In Italy today the system of mutual banks includes 364 banks for a total of over 4,400 branches throughout the Italian territory. The employees of the banks are over 37,000.

In total there are more than 1,200,000 members of the mutual banks and the customers are more than six million. 
Our research fits into this framework as it concentrates on the evidence that small and medium-sized enterprises (SMEs) and family business need the support of credit cooperative banks in order to further exploit the opportunities of expanding their activities.

This study represents a theoretical contribution in the field of credit cooperative banks in Italy and consider their role in developing the efficiency of SMEs and family business. In addition, it can be considered a multidisciplinary analysis because it combines theories regarding both credit cooperative banks in Italy and SMEs and family business in management studies.

As this is the first step of a far deeper analysis, we tried to provide the groundwork for further empirical and qualitative analyses, by improving the existing literature through a conceptual approach.

Despite the limitations of this research, researchers in the field of SMEs and credit cooperative banks can consider the opportunities for further developments of our analysis.

For managers and entrepreneurs of SMEs, a better understanding of the potential benefits of having the financial support of such banks should improve the efficiency of their companies and enhance the setting of the organisational objectives.

The remainder of this study is organised as follows. In Section 2, we provide the literature review. In Section 3, we define the research design. In Section 4, we present the results of our study and, finally, a brief discussions and conclusions are presented in the last part of the research.

\section{Literature review and theoretical background}

The structure and functioning of the banking company has been studied in its entirety by many scholars (Koch and MacDonald, 2007; Ossola, 2005; Giovando and Gianoglio, 1999; Giovando, 1996). Many researchers have studied the bank account (Bocchino et al., 2013; Ossola, 2005), its performance (Berger, 2005) and its financial analysis (Hartvigsen, 1992). Recent studies concentrated on the accounting policy of banks, focusing on the application of the International Accounting Standards (Dezzani et al., 2014) and other specific studies focused on the analysis of the assets and liabilities of the balance sheets (Ossola, 2000).

In addition other researchers have recently analysed the impact of the new capital requirements under Basel III on bank lending rates and loan growth (Kahlert and Wagner, 2015). As a result higher capital requirements, raising the marginal cost of bank funding, have led to higher rates (Cosimano and Hakura, 2011; Elliott, 2009; Laeven and Valencia, 2008).

Some studies focused on the way some financial entities have addressed this moment of global crisis (Crowley, 2015; Costa and Thegeya, 2013; Avdjie et al., 2012; Caprio et al., 2005). Many researchers concentrated on this period of financial crisis (Kapan and Minoiu, 2015; Calvo, 2012), highlighting the crucial role played by the liquidity risk in the stability of a bank, and, more generally, in the financial system (Borio, 2008; Dell'Ariccia et al., 2008). Some have tried to locate the perimeter within which identify the financial risk and study methods for good management, in accordance with the requirements of Basel (Álvarez and Rossignolo 2015; Angelini et al., 2011). 
But recently, the financing of small and medium enterprises has attracted attention because SMEs represent the majority of institutions in lots of countries and because several big companies started as small businesses (de la Torre et al., 2010).

Some researchers analysed the financing to SMEs such as the study conducted through a survey of 95 banks in the world (Beck et al., 2008). This study highlights how banks perceive the SMEs segment is very interesting and profitable, but the other highly dangerous due to the instability of the SMEs sector.

Banks perceive SMEs as important businesses and they have been expanding their involvement with them (de la Torre et al., 2010).

Ioannou and Mihai-Yannaki (2012) synthesised the interdisciplinary literature of relationship management theories as well as banking, economics, and finance theories, and blended this with findings from an ethnographic research platform to discuss the critical variables in the development of bank-SME relationships. In addition, they considered the effect of the recent economic crisis on the bank-SME relationship. The study shows that few banks looked inside their relationship with their SME customers as a means of redressing the crisis' effect and this has detrimental effects on their long-term performance. They proposed recommendations to reduce the crisis negative impact. Moreover, new developments in the technological environment can be used to strengthen the Bank-SME relationship's success and is especially pertinent in such times of financial duress as it can enhance the communication mode of the dyad.

Some scholars have analysed the impact of the global financial crisis on the distribution of credit to SMEs in some countries in Europe like France (Psillaki and Eleftherious, 2015), Spain (Carbo-Valverde et al., 2016), Portugal (Gama and Van Auken, 2015) and UK (Jones-Evans, 2015). Mihai-Yannaki (2012a, 2012b) elaborated a model of risk and crisis management that was implemented in 48 Romanian and Cypriot companies that significantly improved the financial performance of SMEs that employed it.

Other scholars have faced the issue of banks' support to Italian SMEs to enter markets and thus support their internationalisation (Bartoli et al., 2014).

In Italy, the importance of small local banks, such as BCCs, was emphasised in a few studies (Ferri and Messori, 2000). Our research fits into this theme by analysing the banking world of Italian BCCs, supporting the entrepreneurship and the development of the Italian SMEs. We took into consideration data representing the total Italian credit cooperative banks.

Thanks to our analysis, we tried to find a relationship between the banking system and the world of SMEs. However, despite the limitations of research, thanks to this first analysis and theoretical background, researchers in the field of SMEs and credit cooperative banks can consider the opportunities for further developments of our analysis.

In conclusion, one of the goals of this research is to improve the existing literature by using a conceptual approach.

Our research project focuses on the evidence that SMEs and family businesses need the support of the credit cooperative banks, in order to further exploit the opportunity to expand their businesses. 


\section{Research design}

As our research is a theoretical contribution on the role of BCCs supporting the development and growth of SMEs, we analysed all the related documents published on the websites of Credito Cooperativo and Federcasse (Federazione Italiana delle Banche di Credito Cooperativo - Casse Rurali e Artigiane) related to the financial support of BCCs.

This methodology gives evidence of an appropriate approach because there is limited research and theoretical knowledge on the role and related effects of BCCs in the development of activities of SMEs.

The literature review helps create the theoretical bases academics might refer to further examine this topic.

A theoretical framework would contribute to future empirical research in the field and it differs from other studies because it emphasises assumption-challenging in the construction of research questions (Alvesson and Kärreman, 2007, 2011; Sandberg and Tsoukas, 2011).

In particular the research problem in this study is the following:

- Research problem 1: What is the role of credit cooperative banks in Italy to support the growth and development of local businesses?

In order to analyse the role of mutual banks, we took into account for the year 2014 the loans to residents of the local community of each credit cooperative bank in relation to the categories of non-financial companies and producing families.

For non-financial companies, we intend businesses in the manufacturing or third sector field, not banks or other financial institutions.

Producing families instead are family businesses, especially those micro and small companies.

The descriptive analysis on loans, divided also into the specific producing sector, is considered as propaedeutic to answer the first research problem and give a preliminary support to future developments of this study.

\section{Results}

To answer the first research problem, we collected data regarding loans to residents.

There are limits in the granting of loans to individual businesses determined as a percentage of regulatory capital of each bank. Consequently, the BCCs with their respective limited surveillance assets can only finance SMEs. As a result, the data highlighted by the BCCs in the categories of non-financial companies and producing families refer to SMEs and small business craftsmen or traders.

Table 1 shows the data of the global 2014 period of the entire sample for mutual banks in Italy

In Table 1, we can see the percentage of market share in Italy of loans to residents. In particular, BCCs financed more family businesses than non-financial companies. But this result derives from the composition of the local community of each BCC.

We also analysed which sectors were financed by the Italian credit cooperative banks. 
Table 1 Loans to residents of the local community of each credit cooperative bank in 2014

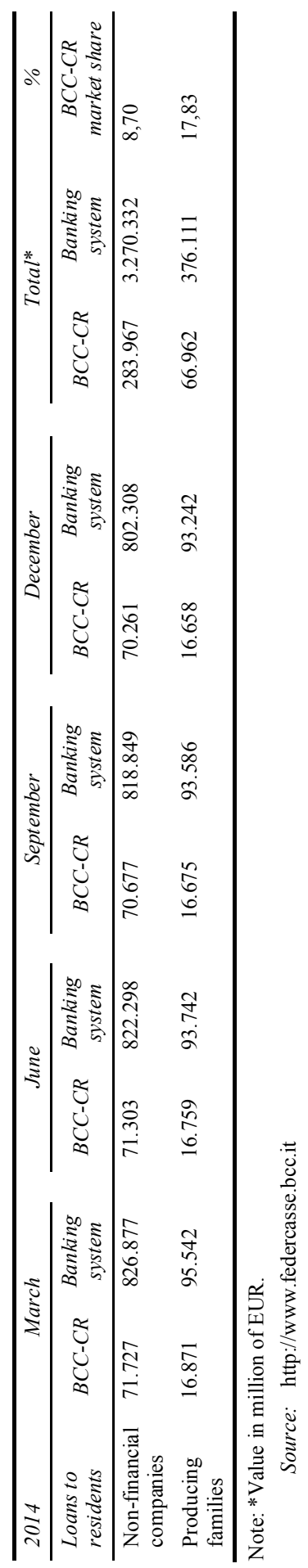


Table 2 Total loans to residents, divided into the specific producing sectors in 2014

\begin{tabular}{lccc}
\hline Total loans to the specific & Total & $\%$ & \\
\cline { 2 - 4 } producing sector (2014) & BCC-CR & Banking system & BCC-CR market share \\
\hline Agriculture and fishing & 32.352 & 177.098 & 18.25 \\
Manufacturing activities & 65.406 & 854.875 & 7.68 \\
Wholesale and retail trade and & 58.860 & 568.153 & 10.38 \\
$\begin{array}{l}\text { repair of motor vehicles and } \\
\text { motorcycles }\end{array}$ & & & \\
Transportation and storage & 8.254 & 157.964 & 5.23 \\
$\begin{array}{l}\text { Accommodation activities and } \\
\text { catering services }\end{array}$ & 26.561 & 149.781 & 17.73 \\
$\begin{array}{l}\text { Information and communication } \\
\text { Professional scientific and }\end{array}$ & 3.124 & 64.357 & 4.85 \\
technical activities & 8.875 & 154.892 & 5.75 \\
$\begin{array}{l}\text { Hire, travel agencies, support } \\
\text { services for businesses }\end{array}$ & 5.160 & 78.315 & 6.60 \\
$\begin{array}{l}\text { Construction and real estate } \\
\text { Other financing in }\end{array}$ & 123.521 & 1.111 .558 & 11.13 \\
manufacturing sector & 18.805 & 329.329 & 5.70 \\
\hline
\end{tabular}

Note: *Value in million of EUR.

Source: http://www.federcasse.bcc.it

Figure 1 Producing sectors of Italian SMEs financed by credit cooperative banks in 2014

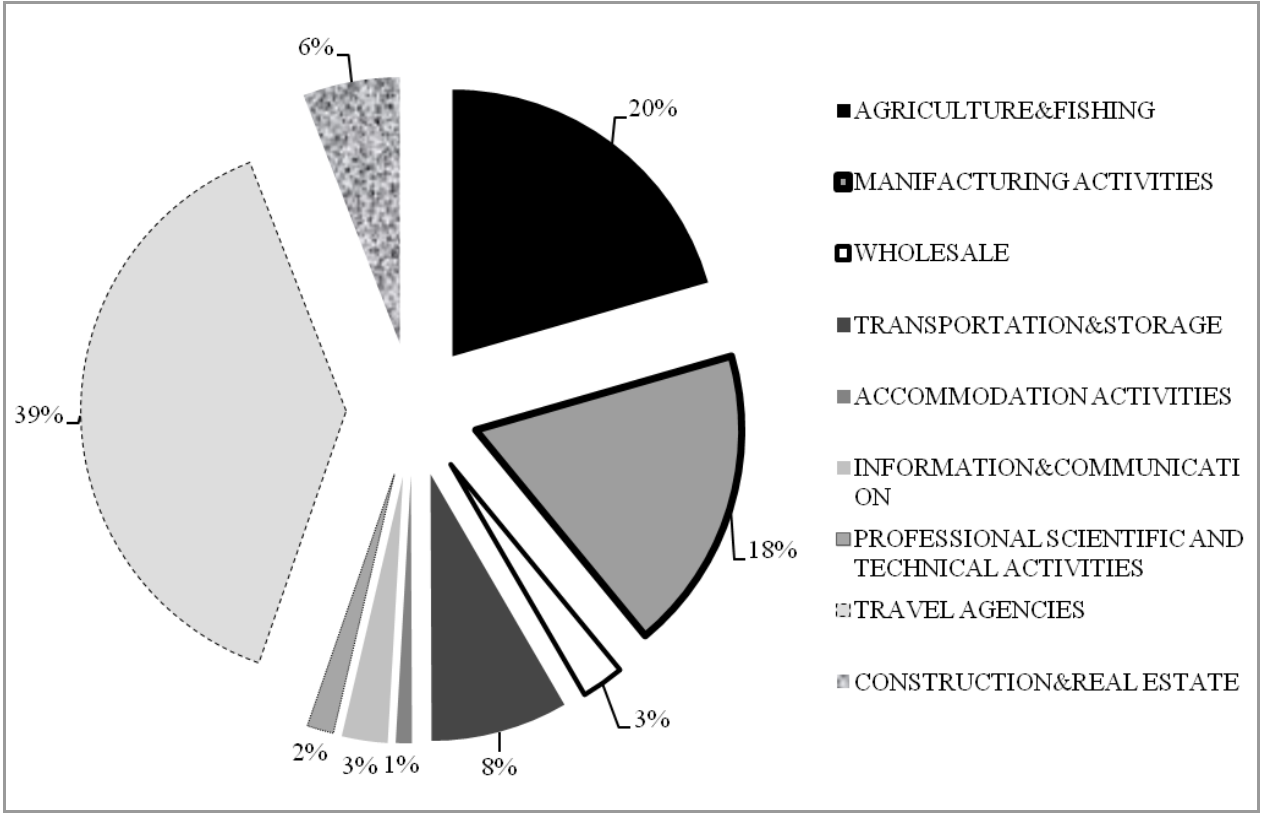

Note: Self-elaborated figure.

Source: http://www.federcasse.bcc.it 
Indeed in Table 2, we can analyse the product categories to whom loans were allocated.

Even in Table 2, there is the percentage of the market share of each sector financed by mutual banks in Italy.

As we can notice, agriculture and fishing, accommodation activities and catering services and constructions and real estate are the sectors mostly financed in Italy in 2014 .

To better analyse the composition of the previous table, Figure 1 reproduces the producing sectors of SMEs in 2014, financed by Italian BCCs.

\section{Discussions and conclusions}

Thanks to the descriptive analysis, it can be underlined how in the year under consideration (2014), the system of credit cooperative banks in Italy consistently financed the SMEs of the non-financial sector and family businesses, covering over $25 \%$ of the Italian market share.

This value in the Italian banking scene is certainly very significant considering that the BCCs have 4,458 banks office in Italy accounting for $14.1 \%$ of the banking system.

Analysing the several sectors funded and their related market shares, as shown in Table 2, we can definitely notice the important role of Italian BCCs in financing those companies.

As mentioned above, the most funded sector is agriculture and fishing. This figure shows the proximity to the territory of the BCCs and how this primary sector has developed in Italy. Other sectors financed were those related to the accommodation activities and catering services and construction and real estate sectors.

If we analyse specifically Figure 1, we can see that the most funded sector is the one of Travel agencies, which is equal to $39 \%$. But this result is well explained by the fact that there are many tourists in our country and that tourism has been growing in recent years.

One of the limits of this analysis is that we concentrated on a single year. The study should be expanded on a panorama of at least five years to see if the phenomenon that was identified in the year 2014 follows a positive or a negative trend. Especially in these years of profound difficulty of obtaining finance for SMEs such analysis would have an important significance.

In addition, this research represents the first step of a far deeper analysis.

In this stage we aimed at providing the groundwork for further empirical and qualitative analyses, because it is fundamental to first understand the theoretical background and find the bases to formulate in subsequent research hypotheses and research questions. 


\section{References}

Álvarez, V.A. and Rossignolo, A.F. (2015) 'Análisis Comparativo De Técnicas (IMA) Para Determinar Capitales Mínimos Regulados Por Basilea, Ante Crisis En Mercados Emergentes (comparative analysis of techniques (IMA) for determining minimum capital regulated by Basel, facing crises in emerging markets),' Social Science Research Network, ODEO, No.8, pp.13-14.

Alvesson, M. and Kärreman, D. (2007) 'Constructing mystery: empirical matters in theory development', Academy of Management Review, Vol. 32, No. 4, pp.1265-1281.

Alvesson, M. and Kärreman, D. (2011) Qualitative Research and Theory Development: Mystery as Method, Sage, London.

Angelini, P., Clerc, L., Cúrdia, V., Gambacorta, L., Gerali, A., Locarno, A., Motto, R., Roeger, W., Van den Heuvel, S. and Vlček, J. (2011) Basel III: Long-Term Impact on Economic Performance and Fluctuations, Federal Reserve Bank of New York Staff Report, No. 485.

Avdjie, S., Zsolt, K. and Elöd, T. (2012) 'The Euro area crisis and cross-border bank lending to emerging markets', BIS Quarterly Review, 11p.

Bartoli, F., Ferri, G., Murro, P. and Rotondi, Z. (2014) 'Bank support and export: evidence from small Italian firm', Journal of Small Business Economics, Vol. 42, No. 2, pp.245-264, DOI:10.1007/s11187-013-9486-8.

Beck, T., Demirgüç-Kunt, A. and Martinez Peria, M.S. (2008) 'Bank financing for SMEs around the world: drivers, obstacles, business models, and lending practices', World Bank Policy Research Working Paper Series, Vol. 1, pp.34-67, World Bank, Washington, DC.

Berger, A.N. (2005) 'Corporate governance and bank performance: a joint analysis of the static, selection, and dynamic effects of domestic, foreign, and state ownership', Journal of Banking \& Finance, Vol. 29, Nos. 8-9, pp.2179-2221.

Bocchino, U., Ossola, G., Giovando, G. and Venuti, F. (2013) Il bilancio delle banche, Giuffrè, Milano.

Borio, C. (2008) The Financial Turmoil of 2007. A Preliminary Assessment and some Policy Considerations, BIS Working Papers, No. 251.

Calvo, G. (2012) 'Financial crises and liquidity shocks a bank-run perspective', European Economic Review, Vol. 56, No. 3, pp.317-326.

Caprio, G., Klingebiel, D., Laeven, L. and Noguera, G. (2005) 'Appendix: banking crisis database', in Honohan, P. and Laeven, L. (Eds.): Systemic Financial Crises: Containment and Resolution, Cambridge University Press, Cambridge, U.K.

Carbo-Valverde, S., Rodriguez-Fernandez, F. and Udell, G.F. (2016) 'Trade credit, the financial crisis, and SME access to finance', Journal of Money, Credit and Banking, Vol. 48, No. 1, pp.113-143.

Cosimano, T.F. and Hakura, D. (2011) Bank Behaviour in Response to Basel III: A Cross-Country Analysis, IMF Working Paper Nos. 11/119 [online] http://ssrn.com/abstract=1860182 or http://dx.doi.org/10.2139/ssrn.1860182 (accessed 20 October 2016).

Costa, N. and Thegeya, A.M. (2013) Financial Soundness Indicators and Banking Crises, Forthcoming, IMF Working Paper WP/13/XX.

Crowley, J. (2015) Central and Commercial Bank Balance Sheet Risk Before, During and After the Global Financial Crisis, International Monetary Funds, Washington, DC.

de la Torre, A., Martínez Pería, M.S. and Schmukler, S.L. (2010) 'Bank involvement with SMEs: beyond relationship lending, Journal of Banking \& Finance, Vol. 34, 2280-2293.

Dell'Ariccia, G., Igan, D. and Laeven, L. (2008) Credit Booms and Lending Standards: Evidence from the Subprime Mortgage Market, IMF Working Papers, 08/106.

Dezzani, F., Biancone, P.P. and Busso, D. (2014) IAS/IFRS, IPSOA, Milano.

Elliott, D.J. (2009) Quantifying the Effects on Lending of Increased Capital Requirements, Brookings Briefing Paper, Brookings Institution, Washington, D.C. 
Ferri, G. and Messori, M. (2000) 'Bank-firm relationships and allocative efficiency in Northeastern and Central Italy and in the South', Journal of Banking and Finance, Vol. 24, No. 6, pp.1067-1095.

Gama, A.P. and Van Auken, H. (2015) 'The interdependence between trade credit and bank lending: commitment in intermediary firm relationships', Journal of Small Business Economics, Vol. 53, No. 4, pp.886-904.

Giovando, G. (1996) La banca in AA.VV., Lezioni di Economia Aziendale, Giuffrè, Milano.

Giovando, G. and Gianoglio, G. (1999) Le banche in AA.VV., Euro ed Economia Aziendale, Giuffrè, Milano.

Hartvigsen, G. (1992) 'Limitations of knowledge-based systems for financial analysis in banking', Expert Systems with Applications, Vol. 4, No. 1, pp.19-32.

Ioannou, M. and Mihai-Yannaki, S. (2012) 'Bank-SME relationships 'poked' by the recent changes in the economic and technological environment', in Kaufman and Panni (Eds.): Customer Centric Marketing Strategies: Tools for Building Organisational Performance, IGI Global, Hershey, USA.

Jones-Evans, D. (2015) 'Access to finance to SMEs at a regional level - the case of Finance Wales', Journal Venture Capital, Vol. 17, Nos. 1-2, pp.27-41.

Kahlert, D. and Wagner, N. (2015) Are Eurozone Banks Undercapitalized? A Stress Testing Approach to Financial Stability, A Stress Testing Approach to Financial Stability, Working Paper, [online] http://ssrn.com/abstract=2568614 or http://dx.doi.org/10.2139/ssrn. 2568614 (accessed 10 October 2016).

Kapan, T. and Minoiu, C. (2015) Balance Sheet Strength and Bank Lending During the Global Financial Crisis [online] http://ssrn.com/abstract=2247185; http://dx.doi.org/10.2139/ssrn.2247185 (accessed 10 September 2016).

Koch, T. and MacDonald, S. (2007) Bank Management, 7th ed., South-Western Cengage Learning, Marson, Ohio.

Laeven, L. and Valencia, F. (2008) Systemic Banking Crisis: A New Database, IMF Working Paper, Nos. 8-224, International Monetary Fund, Washington, D.C.

Mihai Yiannaki, S. (2012a) 'A systemic risk management model for SMEs under financial crisis', International Journal of Organizational Analysis, Vol. 20, No. 4, pp.406-422.

Mihai Yiannaki, S. (2012b) 'Cases illustrating risks and crisis management, in the book', in Rahman and Ramos (Eds.): Cases on SMEs and Open Innovation: Applications and Investigations, pp.238-257, IGI Global, Hershey, USA.

Ossola, G. (2000) I bilanci degli enti finanziari, Giuffrè, Milano

Ossola, G. (2005) Gli schemi del bilancio d'esercizio degli enti creditizi, Giuffrè, Milano.

Psillaki, M. and Eleftherious, K. (2015) 'Trade credit, bank credit, and flight to quality: evidence from French SMEs', Journal of Small Business Management, Vol. 53, No. 4, pp.1219-1240.

Sandberg, J. and Tsoukas, H. (2011) 'Grasping the logic of practice. Theorizing through practical rationality’, Academy of Management Review, Vol. 36, No. 2, pp.338-360. 